\title{
Development of Moving Equipment for Fishermen's Catches using the Portable Conveyor System
}

\author{
Herry Susanto ${ }^{1,2}$, Roy Hendroko Setyobudi ${ }^{2,3 *}$, Syukri Muhammad Nur ${ }^{2}$, Erkata Yandri $^{2}$, \\ Aep Saepul Uyun ${ }^{1,2}$, Abubakar Yaro ${ }^{4}$, Kamaruddin Abdullah ${ }^{2}$, Satriyo Krido Wahono ${ }^{5}$, \\ Juris Burlakovs ${ }^{6}$, and Yogo Adhi Nugroho ${ }^{7,8}$ \\ ${ }^{1}$ Department of Mechanical Engineering, Darma Persada University, Jl. Taman Malaka Selatan \\ No.22, Jakarta Timur, 13450, Indonesia \\ ${ }^{2}$ Graduate School of Renewable Energy, Darma Persada University, Jl. Taman Malaka Selatan No.22, \\ Jakarta Timur, 13450, Indonesia \\ ${ }^{3}$ Department of Agriculture Science, Postgraduate Program, University of Muhammadiyah Malang, \\ Jl. Raya Tlogomas No.246, Malang, 65145, Indonesia \\ ${ }^{4}$ Institute of Health Sciences \& Research, AHRO Scientific Publishing, 272 Bath Street, \\ Glasgow G2 4JR, Scotland, UK \\ ${ }^{5}$ Research Division for Natural Product Technology - Indonesian Institute of Sciences, \\ Jl. Jogja - Wonosari, km 31.5, Gunung Kidul, Special Region Yogyakarta 55861, Indonesia \\ ${ }^{6}$ Department of Water Management, Estonian University of Life Sciences, \\ Friedrich Reinhold Kreutzwaldi la 51014 Tartu, Estonia \\ ${ }^{7}$ Individual Researcher, Alumni Graduate School of IPB University, Bogor, Indonesia \\ ${ }^{8}$ Data Processing, Rumah Paper - Editage Services, J1. Tokala No.1, Malang 65146, \\ East Java, Indonesia
}

\begin{abstract}
Indonesia is an archipelago that has a wealth of marine fish resources, and the country with the second-longest coastline in the world. The improvement witnessed in the economy of Indonesia in recent years, is as a result of the growth experienced in various sectors, among which is the fisheries and marine. To overcome this problem, a portable conveyor system of moving equipment for fishermen's catches was designed. It can be placed at the dock or port where the fishermen are anchored and unloading the fishermen's catches from the sea. It designed to have the ability to move up and down in the moving frame, making this conveyor system can be used both in high tides and low tides of seawater level conditions. The advantage of this portable conveyor system is could be done continuously with a little human power. Other than that, from the results of the calculations, known that with increasing motor rotation, the required traveling time will only become shorter. The resulting conveyor capacity shows an increase. Also, it can use drive motors that are available on the market with a power capacity of $0.37 \mathrm{~kW}$. Therefore, the process of this portable conveyor system can be more efficient.
\end{abstract}

Key words: Marine fish development, prosperity, renewable energy, sovereignty, sustainability

\footnotetext{
*Corresponding author: roy_hendroko@ hotmail.com
} 


\section{Introduction}

Indonesia is an archipelago that has a wealth of marine fish resources with an estimated sea area of $5.8 \times 10^{6} \mathrm{~km}^{2}$ and is the country with the second-longest coastline in the world, which is $81000 \mathrm{~km}$ [1]. The improvement witnessed in the economy of Indonesia in recent years, is as a result of the growth experienced in various sectors, among which is the fisheries and marine. The enormous resources available in the fisheries sector have the potential to be the major driver of the national economy [2]. During President Joko Widodo's leadership, the government worked hard to restore Indonesia as a maritime country. It is striving hard to restore fisheries and marine life as guardians of the nation's sustainability. The mission of marine and fisheries development, formulated in three pillars, namely sovereignty, sustainability, and prosperity [3]. In fact, there are at least five approaches in the empowerment of fishermen that need to be developed in order to run effectively, that is, development of alternative livelihoods, fund access, technology access, market access, and development of collective action [4]. Therefore, at this time developed various kinds of appropriate technology to facilitate and streamline the work of the fishermen.

The need for fishermen is the ease in distributing their catches. When the fishermen just leaned on the dock after returning from fishing, they need a tool that can move their catch from the ship to the mainland more quickly and efficiently without requiring too many people to lift it. One of the proper tools used to move the catches of the fishermen is the conveyor. At this time, various types of conveyors were developed. Some of them have developed a type of conveyor for foodstuff dryers [5], some are developing a type of automation conveyor for industrial purposes [6-10], and some are developing a type of automation conveyor for mining purposes [11-14]. Hence the development of conveyor types to make it easier to transport and move the catches of the fishermen becomes a challenge and also a solution for fishermen communities in their efforts to improve their economy and prepare for facing increasingly fierce competition.

\section{Research methodology}

\subsection{Research flow diagram}

In this paper, the research steps are shown in the following research flow diagram in Figure 1: 


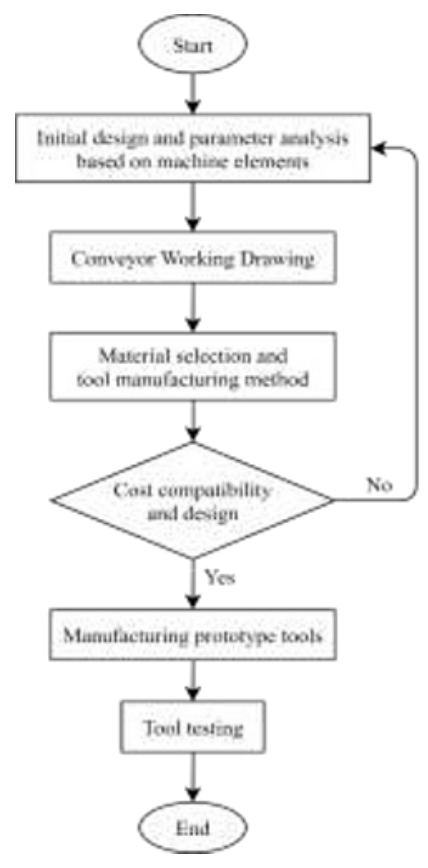

Fig. 1. Research flow diagram.

\subsection{The portable conveyor of moving equipment for fishermen's catches}

Design of the portable conveyor of moving equipment for fishermen's catches to be studied can be seen in Figure 2, the advantage of this portable conveyor system is the moving process can take place continuously. The main components of the portable conveyor system shown as in Figure 2:

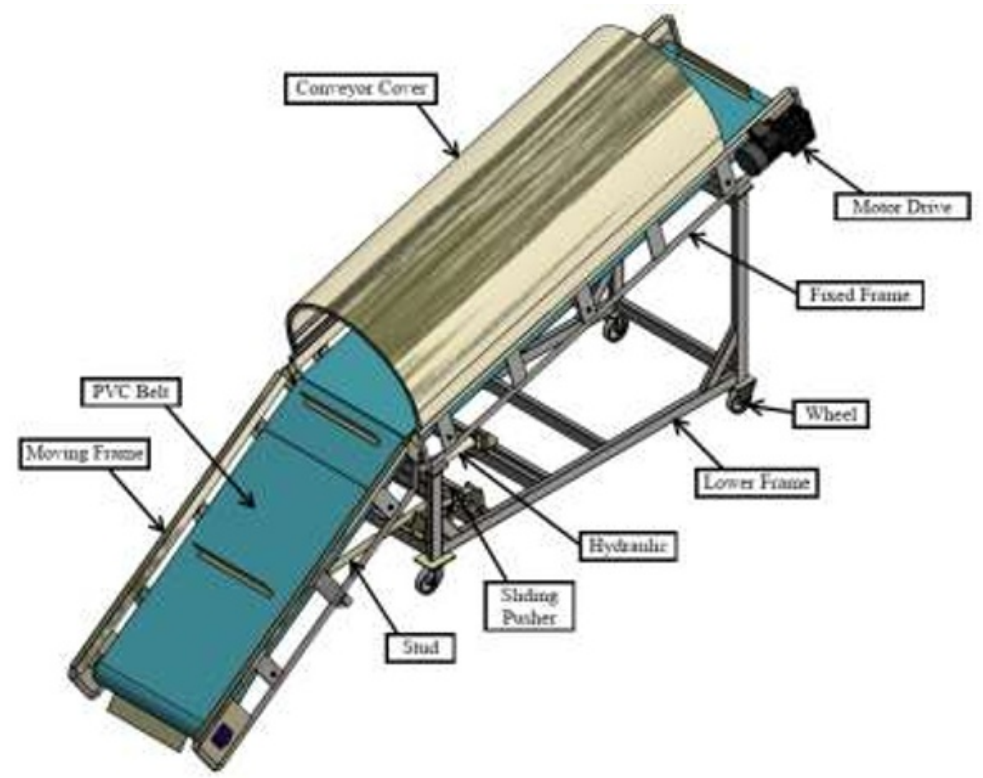

Fig. 2. The portable table conveyor of moving equipment for fishermen's catches. 


\subsection{Working principle of the portable conveyor of moving equipment for fishermen's catches}

The portable conveyor as moving equipment for fishermen's catches. It can be placed at the dock or port where the fishermen are anchored and unloading the fishermen's catches from the sea. It is designed to have the ability to move up and down in the moving frame. Adjusting the movement up and down in the moving frame, carried out adjusting to the conditions high tides and low tides of seawater level. During high tides of seawater level, the position of the moving frame is at the position of the top point, as shown in Figure 3.

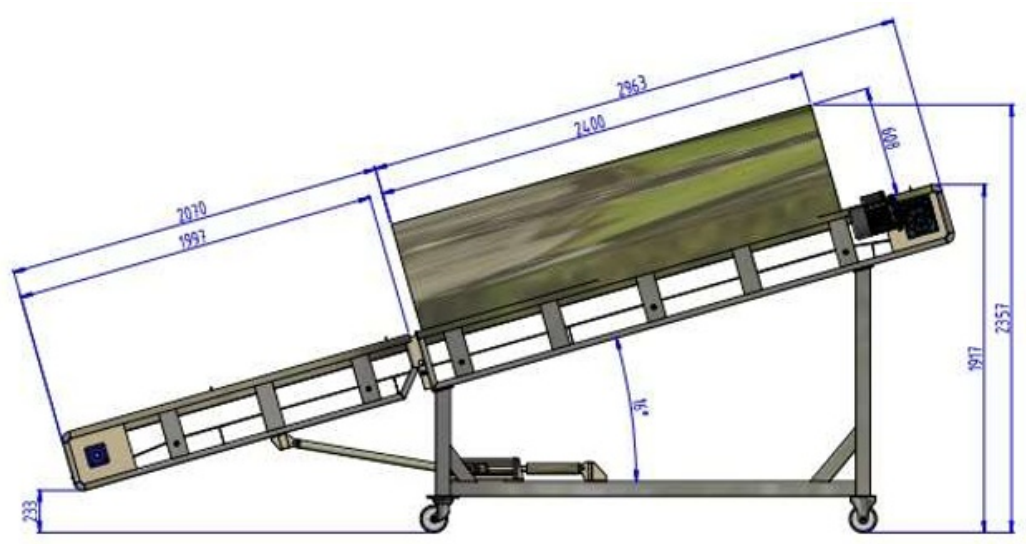

Fig. 3. The Portable conveyor at the top point position.

While at low tides of seawater level, the position of the moving frame is at the position of the bottom point, as shown in Figure 4.

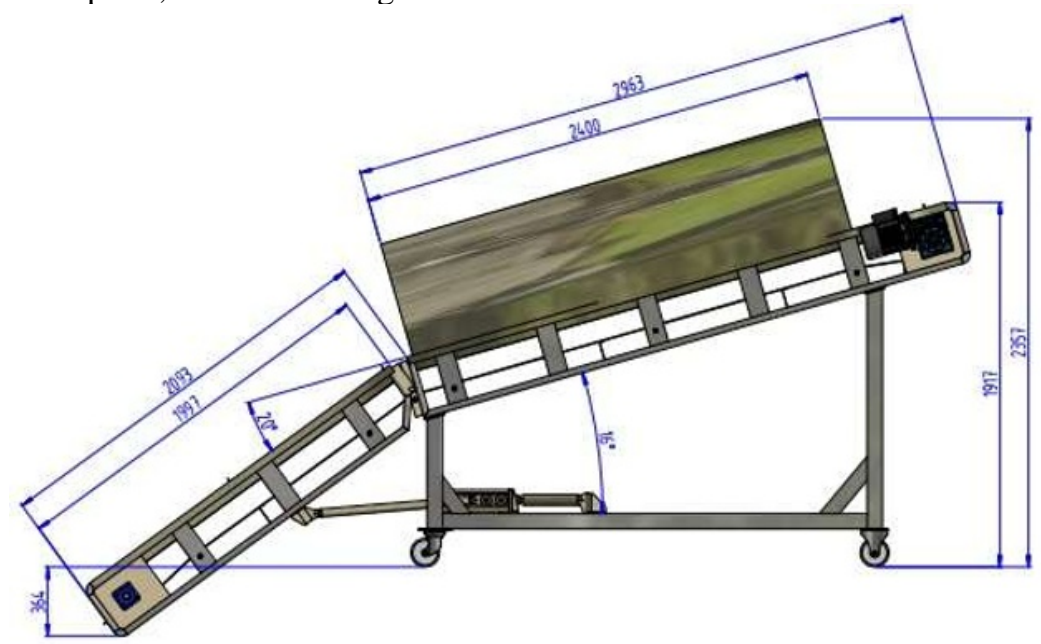

Fig. 4. The portable conveyor at the bottom point position.

Hence with these arrangements, the fishermen's catches will be easily moved from the ship to the mainland without being affected by high tides and low tides of seawater level conditions. It can even be directly transferred to a cold storage car by placing the cold storage car in front of the portable conveyor. 


\section{Equation}

This portable conveyor system is designed to be used to transport or move loads from the fishermen's catches, especially fish. It is designed with upward movement direction, as shown in Figure 3 and Figure 4, that have been shown previously. To get optimal capabilities from this portable conveyor design, then this research will follow some design parameters that are needed, such as the conveyor belt speed, the travel time of the load moved, the maximum capacity, and the required motor power. It is calculated using the Equation (1) to the Equation (9) $[5,12,15]$. The conveyor belt speed based on the Equation (1):

$$
V_{c}=\frac{\pi \cdot D \cdot n}{60000}
$$

Then calculate the travel time of the load moved using the Equation (2):

$$
t=\frac{L}{V_{c}}
$$

The maximum capacity can be calculated using the Equation (3):

$$
Q_{c}=\frac{3600}{1000} \cdot A \cdot V_{c} \cdot \rho
$$

The mass of material moved can be calculated using the Equation (4):

$$
W_{m}=\frac{Q_{c}}{V_{c}}
$$

The effective tensile force of the belt can be calculated using the Equation (5):

$$
F_{e}=\left(W_{m} \cdot H\right)+\left(0.04\left(2 \cdot W_{b}+W_{m}\right) \cdot L\right)
$$

The maximum tensile force of the belt can be calculated using the Equation (6):

$$
F_{\max }=F_{e} \cdot m
$$

The working tensile force per unit width of the belt can be calculated using the Equation (7):

$$
F_{k}=\frac{F_{\max }}{l}
$$

The required power can be calculated using the Equation (8):

$$
P=F_{e} \cdot V_{c}
$$

The required motor power can be calculated using the Equation (9):

$$
P_{m}=\frac{P}{\eta_{m}}
$$

where : $\quad \mathrm{V}_{\mathrm{c}} \quad=$ Conveyor belt speed $\left(\mathrm{m} \mathrm{s}^{-1}\right)$

$\mathrm{D} \quad=$ Drive pulley diameter $(\mathrm{mm})$

$\mathrm{n} \quad=$ Drive pulley rotation $(\mathrm{rpm})$ 
$\mathrm{t} \quad=$ Travel time of the load moved $(\mathrm{s})$

$\mathrm{L} \quad=$ Conveyor length $(\mathrm{m})$

$\mathrm{Q}_{\mathrm{c}} \quad=$ Maximum capacity $\left(\mathrm{t} \mathrm{h}^{-1}\right)$

A = Material moved cross-sectional area $\left(\mathrm{m}^{2}\right)$

$\rho \quad=$ Density of material moved (s)

$\mathrm{W}_{\mathrm{m}}=$ Mass of material moved $\left(\mathrm{kg} \mathrm{m}^{-1}\right)$

$\mathrm{W}_{\mathrm{b}}=$ Mass of belt $\left(\mathrm{kg} \mathrm{m}^{-1}\right)$

$\mathrm{F}_{\mathrm{e}} \quad=$ Effective tensile force of belt $(\mathrm{N})$

$\mathrm{H} \quad=$ Height difference of conveyor $(\mathrm{m})$

$\mathrm{L} \quad=$ Distance moved $(\mathrm{m})$

$\mathrm{F}_{\max }=$ Maximum tensile force of belt $(\mathrm{N})$

$\mathrm{m}=$ Drive factor (1.4)

$\mathrm{F}_{\mathrm{k}} \quad=$ Working tensile force per unit width of belt $\left(\mathrm{N} \mathrm{mm}^{-1}\right)$

$1=$ Belt width $(\mathrm{mm})$

$\mathrm{P} \quad=$ Required power $(\mathrm{W})$

$\mathrm{P}_{\mathrm{m}} \quad=$ Required motor power $(\mathrm{W})$

$\eta_{\mathrm{m}}=$ Motor efficiency $(0.85)$

\section{Result and discussion}

\subsection{Calculation and analysis of the portable conveyor of moving equipment for fishermen's caches performance}

The following are the initial design parameter to calculate the performance of this portable conveyor system. These data are shown in Table 1.

Table 1. Initial design parameter of a portable conveyor system.

\begin{tabular}{clcc}
\hline No & \multicolumn{1}{c}{ Parameters } & Value & Unit \\
\hline 1 & Material moved & Fish & \\
\hline 2 & Equipment type & Conveyor & \\
\hline 3 & Motor rotation $(\mathrm{n})$ & 1400 & $\mathrm{rpm}$ \\
\hline 4 & Gearbox ratio & $1: 20$ & \\
\hline 5 & Motor rotation output $\left(\mathrm{n}_{\mathrm{o}}\right)$ & 70 & $\mathrm{rpm}$ \\
\hline 6 & Drive pulley diameter $(\mathrm{D})$ & 115 & $\mathrm{~mm}$ \\
\hline 7 & Conveyor length $(\mathrm{L})$ & 5 & $\mathrm{~m}$ \\
\hline 8 & Material moved cross-sectional area $(\mathrm{A})$ & 0.08 & $\mathrm{~m}^{2}$ \\
\hline 9 & Density of material moved $(\rho)$ & 920 & $\mathrm{~kg} \mathrm{~m}^{-3}$ \\
\hline 10 & Height difference of conveyor $(\mathrm{H})$ & 1.4 & $\mathrm{~m}$ \\
\hline 11 & Mass of Belt $\left(\mathrm{W}_{\mathrm{b}}\right)$ & 3.6 & $\mathrm{~kg} \mathrm{~m}^{-1}$ \\
\hline 12 & Drive factor $(\mathrm{m})$ & 1.4 & \\
\hline 13 & Belt width $(\mathrm{l})$ & 800 & $\mathrm{~mm}^{-}$ \\
\hline 14 & Motor efficiency $\left(\eta_{\mathrm{m}}\right)$ & 0.85 & \\
\hline
\end{tabular}

Note: $1 \mathrm{rpm}=1 / 60 \mathrm{~Hz}(\mathrm{SI})$ 
The data in Table 1 will be used as a reference to calculate the portable conveyor system performance using the Equation (1) to the Equation (9), as shown in Table 2.

Table 2. Calculation results of the portable conveyor system performance.

\begin{tabular}{|c|c|c|c|c|c|c|c|c|c|}
\hline $\begin{array}{l}\text { Output } \\
\left(\mathbf{r p m}^{*}\right)\end{array}$ & $\begin{array}{c}\mathbf{V}_{\mathbf{c}} \\
\left(\mathrm{m} \mathrm{s}^{-1}\right)\end{array}$ & $\begin{array}{c}\mathbf{t} \\
(\mathbf{s})\end{array}$ & $\begin{array}{c}Q_{c} \\
\left(t^{-1}\right)\end{array}$ & $\begin{array}{c}W_{m} \\
\left(\mathrm{~kg} \mathrm{~m}^{-1}\right)\end{array}$ & $\begin{array}{l}\mathbf{F e}_{\mathbf{e}} \\
(\mathbf{N})\end{array}$ & $\begin{array}{r}\text { F }_{\max } \\
(\mathbf{N})\end{array}$ & $\begin{array}{c}F_{k} \\
\left(\mathrm{~N} \mathrm{~mm}^{-1}\right)\end{array}$ & $\begin{array}{c}\mathbf{P} \\
(\mathbf{W})\end{array}$ & $\begin{array}{l}\mathbf{P m}_{\mathbf{m}} \\
(\mathbf{W})\end{array}$ \\
\hline 61 & 0.367 & 13.61 & 97.3 & 265 & 425 & 596 & 0.7 & 156.2 & 183.8 \\
\hline 62 & 0.373 & 13.39 & 98.9 & 265 & 425 & 596 & 0.7 & 158.8 & 186.8 \\
\hline 63 & 0.379 & 13.18 & 100.5 & 265 & 425 & 596 & 0.7 & 161.4 & 189.8 \\
\hline 64 & 0.385 & 12.97 & 102.1 & 265 & 425 & 596 & 0.7 & 163.9 & 192.9 \\
\hline 65 & 0.391 & 12.77 & 103.7 & 265 & 425 & 596 & 0.7 & 166.5 & 195.9 \\
\hline 66 & 0.397 & 12.58 & 105.3 & 265 & 425 & 596 & 0.7 & 169.0 & 198.9 \\
\hline 67 & 0.403 & 12.39 & 106.9 & 265 & 425 & 596 & 0.7 & 171.6 & 201.9 \\
\hline 68 & 0.409 & 12.21 & 108.5 & 265 & 425 & 596 & 0.7 & 174.2 & 204.9 \\
\hline 69 & 0.415 & 12.03 & 110.1 & 265 & 425 & 596 & 0.7 & 176.7 & 207.9 \\
\hline 70 & 0.421 & 11.86 & 111.7 & 265 & 425 & 596 & 0.7 & 179.3 & 210.9 \\
\hline
\end{tabular}

*Note: $1 \mathrm{rpm}=1 / 60 \mathrm{~Hz}(\mathrm{SI})$

The graphs in Figure 5 and Figure 6 are graphs of calculation results of traveling time, capacity, and required motor power:

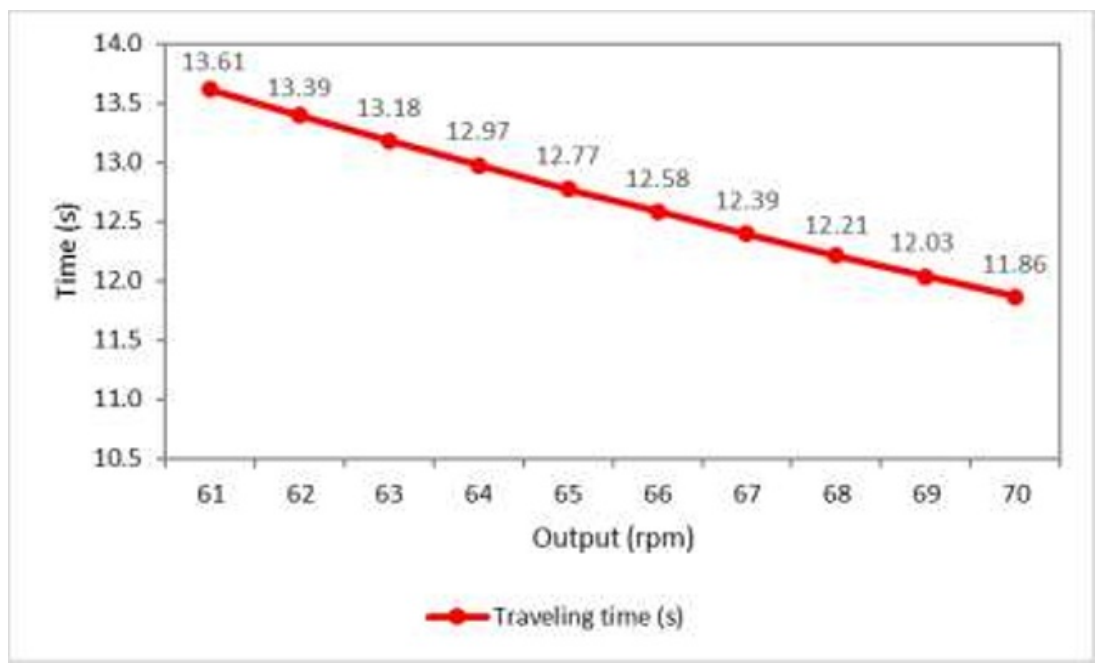

Fig. 5. Graph of traveling time vs motor rotation output. 


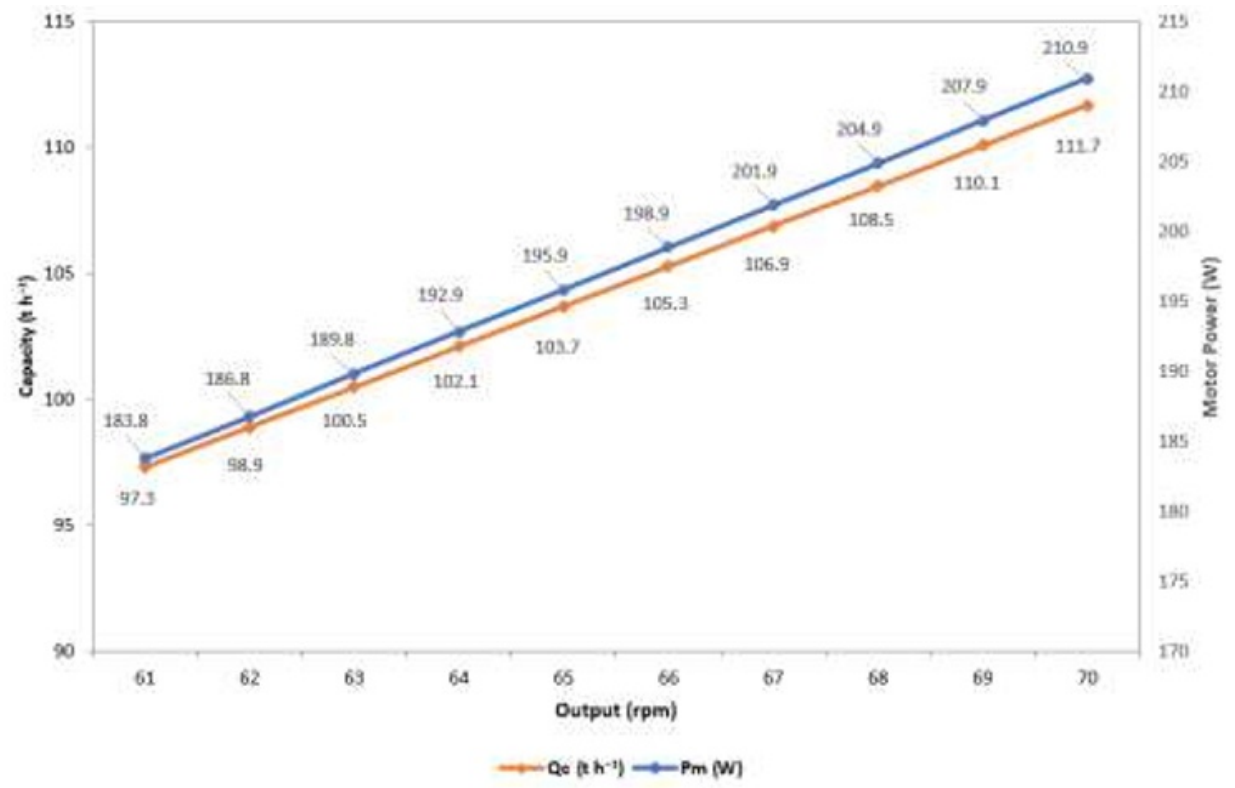

Fig. 6. Graph of capacity \& motor power vs motor rotation output.

\subsection{Discussion of the portable conveyor of moving equipment for fishermen's catches}

In the development of the portable conveyor systems design as moving equipment of fishermen's catches, there are several things that must be considered properly, i.e., this equipment will be used in a place close to a river or sea that has high salt content and allows corrosion to occur, then all components, especially in the frame, must be coated with an anti-corrosion coating through the galvanic or hotdipe process $[5,15]$. Then this equipment might be used also in areas that are still not reached by electricity. Hence, it needs to think about and develop electrical energy sources; the solution is by providing generators or power plants that use renewable energy.

Susanto et al. [5] has conducted research by utilizing solar energy as a source of energy for the drying machine. Reference [15] utilize biogas energy as a source of energy in the livestock feed making machines. Novianto et al. [16] has tested the performance of the smart microgrid system by utilizing solar and wind energy sources. Abdullah et al. [17] has developed an Energy Self-Sufficient Village in Tangsi Jaya, Gunung Halu, West Java, Indonesia. Reference [17] also describes biogas and bioethanol, which is obtained from the utilization of waste from local small industries to energy.

Fish waste pile up at the Fishing Ports (Pelabuhan Perikanan), Fish Auctions (TPI Tempat Pelelangan Ikan), or Fish Auctions Center (PPI - Pusat Pelelangan Ikan). The fish waste is confirmed to pollute the environment and have a negative impact on the health of fishery stakeholders [18] even though fish waste is a potential source of renewable energy.

Reference [19-21] presented the utilization of fish waste to biogas. This fish waste digester can be used for multi feedstock by utilizing food waste and other organic waste around the fishing port. The digester is also suitable to be connected to the pipe from the latrine(s) located at the Fishing Port. Reference $[15,17]$ have described digester mixed latrine(s) technology. The possibility of $\mathrm{pH}$ fluctuation due to the diversity of feedstocks can be overcome with a two-stage digester [22, 23]. 
Fish waste can also be used as another renewable energy source. Several studies proved that fish waste is feasible as a raw material for biodiesel or bio-oil [24-26]. With the availability of biogas, biodiesel, and bio-oil from fish waste, fishing ports can actually be locations for Energy Self-Sufficient for the moving equipment of fishermen's catches using the portable conveyor system that is being developed.

Moreover, this equipment is used to move fishermen's catches and come from the sea, hence that the fishy smell will stick to the equipment a lot. Then keep in mind the cleaning process and make a schedule. Furthermore, it needs to pay attention to the maintenance time of this equipment. Hence it can be more durable and be used longer [5, 15]. Also, because the required motor power at maximum conditions is $210.9 \mathrm{~W}$, hence it can use motors that are available on the market with a power capacity of $0.37 \mathrm{~kW}$.

\section{Conclusion}

From the results of the calculations, it is varying the motor rotation output from a minimum rotation of $61 \mathrm{rpm}$ to a maximum rotation of $70 \mathrm{rpm}$. The traveling time was reduced by $12.86 \%$. The conveyor capacity increases by around $12.89 \%$. Also, the required motor power at maximum conditions is $210.9 \mathrm{~W}$. Moreover, by adjusting the movement on the moving frame, making this conveyor system can be used in high tides and low tides of seawater level conditions.

\section{References}

1. M.A. Alpharesy, Z. Anna, A. Yustiati, Jurnal Perikanan dan Kelautan, 3,1:11 16(2012). [in Bahasa Indonesia]. http://jurnal.unpad.ac.id/jpk/article/view/3547

2. M.M. Lubis, I. Effendi, Y. Lubis, S. Lugu, IOP Conf. Series: Earth and Environmental Science, 348:012039(2019). https://iopscience.iop.org/article/10.1088/1755-1315/348/1/012039/pdf

3. S. Oktavilia, Firmansyah, F.X. Sugiyanto, M.A. Rachman, IOP Conf. Series: Earth and Environmental Science, 246:012006(2019).

https://iopscience.iop.org/article/10.1088/1755-1315/246/1/012006/pdf

4. K.D. Maani, A. Firnaldi, H. Fajri, MATEC Web of Conferences, 229:01004(2018) https://www.matecconferences.org/articles/matecconf/pdf/2018/88/matecconf_icdm2018_01004.pdf

5. H. Susanto, R.H. Setyobudi, Y. Chan, S.M. Nur, E. Yandri, J. Burlakovs, et al., IOP Conf. Series: Earth and Environmental Science, 490:012009(2020).

https://iopscience.iop.org/article/10.1088/1755-1315/490/1/012009/pdf

6. I. Satria, M. Rusli, MATEC Web of Conferences, 166:01007(2018) https://www.matecconferences.org/articles/matecconf/pdf/2018/25/matecconf icmaa2018 01007.pdf

7. C. Suvanjumrat, W. Suwannahong, S. Thongkom, MATEC Web of Conferences, 95:06006(2017).

https://www.matecconferences.org/articles/matecconf/pdf/2017/09/matecconf_icmme2017 06006.pdf

8. M. Blatnický, J. Dižo, M. Blatnická, MATEC Web of Conferences, 157:01002(2018) https://www.matecconferences.org/articles/matecconf/pdf/2018/16/matecconf_mms2018 01002.pdf

9. F. Blaga, I. Stanasel, MATEC Web of Conferences, 184:03002(2018). https://www.matecconferences.org/articles/matecconf/pdf/2018/43/matecconf_oradea2018_03002.pdf 
10. Syawaluddin, A. Hidayat, Sintek Jurnal: Jurnal Ilmiah Teknik Mesin, 3,2: 32-42(2009). [in Bahasa Indonesia].

https://jurnal.umj.ac.id/index.php/sintek/article/view/103/85

11. S. Sahrupi, J. Juriantoro, Jurnal Sistem dan Manajemen Industri, 2,1:51-57(2018). [in Bahasa Indonesia] https://e-jurnal.lppmunsera.org/index.php/JSMI/article/view/568/pdf

12. D. Cahyadi, G.F. Azis, Sintek Jurnal: Jurnal Ilmiah Teknik Mesin, 9,1:13-17. (2015). [in Bahasa Indonesia] https://jurnal.umj.ac.id/index.php/sintek/article/view/299

13. I.M.N. Arijaya, Jurnal Resistor, 2,2:126-135(2019). [in Bahasa Indonesia] https://ejournal.stiki-indonesia.ac.id/index.php/jurnalresistor/article/view/363/170

14. H. Soleh, W. Euis, H. Witarsa, M. Verdian, D. Yuniarti, Caroline, Mikrotiga: Electrical Engineering Journal, 1,2:8-13(2014). [in Bahasa Indonesia] https://ejournal.unsri.ac.id/index.php/jmt/article/view/1595

15. H. Susanto, R.H. Setyobudi, D. Sugiyanto, S.M. Nur, E. Yandri, H. Herianto, et al., E3S Web of Conferences 188:00010(2020).

https://doi.org/10.1051/e3sconf/202018800010

16. B. Novianto, K. Abdullah, A.S. Uyun, E. Yandri, S.M. Nur, H. Susanto, et al., E3S Web of Conferences 188:00005(2020). https://doi.org/10.1051/e3sconf/202018800005

17. K. Abdullah, A.S. Uyun, R. Soegeng, E. Suherman, H. Susanto, R.H. Setyobudi, et al., E3S Web of Conferences 188:00016(2020). https://doi.org/10.1051/e3sconf/202018800016

18. K. Khoiron, A.N. Probandari, W. Setyaningsih, H.S. Kasjono, R.H. Setyobudi, O. Anne. Ann Trop \& Public Health S463, 23,3(A):60-67. http://doi.org/10.36295/ASRO.2020.23316

19. F. Bücker, M. Marder, M.R. Peiter, D.N. Lehn, V.M. Esquerdo, L.A. de Almeida Pinto, et al, Renew. Energy, 147(1):798-805(2020).

https://doi.org/10.1016/j.renene.2019.08.140

20. G.K. Kafle, S.H. Kim, K.I. Sung, Bioresour. Technol., 127:326-336(2013). https://doi.org/10.1016/j.biortech.2012.09.032

21. L.S. Cadavid-Rodrígueza, M.A. Vargas-Muñoz, J. Plácido, Sustain. Energy Technol. Assess., 34:110-115(2019).

https://doi.org/10.1016/j.seta.2019.05.006

22. P.G. Adinurani, R.H. Setyobudi, S.K. Wahono, M. Mel, A. Nindita, E. Purbajanti, et al., Proc. Pakistan Acad. Sc. Part B 54,1:47-57(2017). , 54,1:47-57(2017). http://www.paspk.org/wp-content/uploads/2017/03/Proceedings-B.-Life-Sciences541-March-2017.pdf

23. R.H. Setyobudi, A.Sasmito, P.G. Adinurani, A. Nindita, A.S. Yudhanto, Y.A. Nugroho, et al, Energy Procedia, 65,2015:300-308(2015). https://doi.org/10.1016/j.egypro.2015.01.056

24. P. Jayasinghe, K. Hawbold, Renew. Sust. Energ. Rev., 16(1):798-821(2012). https://doi.org/10.1016/j.rser.2011.09.005

25. S.S. Harsono, R.H. Setyobudi, T. Zeemani, Jurnal Teknologi, 78,4-2:215-219(2016). http://doi.org/10.11113/jt.v78.8210

26. R. Yahyaee, B. Ghobadian, G. Najafi, Renew. Sust. Energ. Rev., 17:312-319(2013). https://doi.org/10.1016/j.rser.2012.09.025 